\title{
Study of Building License Services at Malang Regency \\ (Policy Implementation Delegation of the Regent's Authority to the Camat in Kepanjen District, Malang Regency, Indonesia)
}

\section{Hapsari Dwi Hastuti, Sri Hartini Jatmikowati, and Tommy Hariyanto}

University of Merdeka Malang, Indonesia

\begin{abstract}
As the implementation of Malang Regent Regulation concerning Delegation of Regent's Authority to District Leaders or called Camat. Part of the authority of the Regent can be delegated to the Camat as policy implementer at the District level. It aims to provide effective and efficient services. Building Permit Service is one of the public services that can be held at the sub-district level. The service for building permits is very important considering that the legality that is owned by the community towards building ownership will provide a financial value to the building and also the community will have legal power if a problem occurs one day. The process of obtaining a building permit on average can be completed within 14 working days. The application process must complete the application form and must collect the requirements that have been set. If the requirements have been met, the file will be validated and a location survey schedule will be made to match the data in the file with conditions in the field. After obtaining a match with the conditions in the field, a certificate of building construction permit will be drafted. In the service of building permits, the applicant will be charged a retribution fee which has been stipulated in the Malang Regency Regional Regulation, concerning Certain Licensing Retribution. If there are no errors, the certificate will be signed by the Head of the Kepanjen District and can then be submitted to the applicant. The provisional results of research conducted in Kepanjen District, Malang Regency on the implementation of building permits have been running according to the procedures set out in Malang Regent Regulation concerning Delegation of Regent's Authority to Camat.
\end{abstract}

Keywords: Building permit, Malang Regent Regulation.

\section{INTRODUCTION}

With the delegation of authority, the regional government can stipulate regional regulations and other regulations to implement them. Autonomy and the task of assisting local government management arrangements. The highest delegation of authority is at the ministry level, and the lowest board of power is at the district level.

According to Rosramadhana three prominent aspects support the success of regional autonomy, namely supervision, control, and inspection [4]. These three things are fundamental to the implementation of regional autonomy. Management refers to the level of activities carried out outside the executive, namely the community and Assembly at provincial (DPRD), for monitoring the provincial government's performance. Control is a mechanism carried out by the executive (Local Government) to ensure the implementation of management systems and policies properly so that organizational goals can be achieved. Examination is an activity by parties who have independence and have the professional competence to check whether the results of local government performance are by existing standards or criteria.

In his book entitled Strategy and Socio-Political Problems of the Indonesian Regional Autonomy Government state that conceptually, the implementation of regional autonomy in Indonesia is based on three main objectives, which include political goals, organizational goals, and economic goals. The administrative objective to be achieved by implementing regional autonomy is the division of government affairs between the center and the regions. Implementing regional independence makes it easier for autonomous areas to run the government. One of them is the implementation of public services [4].

The implementation of public services is the administration of government directly related to the community, where the purpose of providing services is to provide welfare to the community. The realization of the community's interest by offering services that can be affordable, easy, fast, and efficient both in terms of time and financing. Series of activities in the context of fulfilling service needs by statutory regulations for every citizen and resident of goods, services, or administrative services provided by the administration of public services. In the focus of public administration research in Indonesia, public services still require 
comprehensive attention and completion. It is undeniable that the government continues to improve public services to the community in line with the demands of society and the changing times. Every human being needs assistance; even at the extreme, it can be said that service cannot be separated from human life ${ }^{[5]}$. Society always demands quality public services from bureaucrats, although these demands are often not in line with expectations because empirically, public services that have occurred so far are still characterized by: convoluted, slow, expensive, and tiring. Therefore, public sector organizations are required to make changes in solving problems to meet the needs and demands of the community.

In connection with what was conveyed according to research conducted by the Governance and Decentralization Survey $2002^{[6]}$ found that there are at least three critical problems that need to be addressed in providing public services after the implementation of regional autonomy regulations, namely the magnitude of service discrimination, not the existence of service certainty, and the low level of community satisfaction with public services. There are many cases of levies carried out by irresponsible persons who take advantage of the administration of public services. Not much different from the results of a study conducted by the Governance Assessment Survey.

The research location was chosen in Kepanjen District, Malang Regency, which is the capital of Malang Regency. The Malang Regency Government Office is located in the Kepanjen District, so the central government is in the Kepanjen District. So the Kepanjen District is a benchmark for implementing community services for other sub-districts in Malang Regency.

Given the importance of having a building permit, researchers feel interested in further describing and explaining this issue. Then the researchers will conduct a study with the title Building Permit Services (Study on Policy Implementation Based on Malang

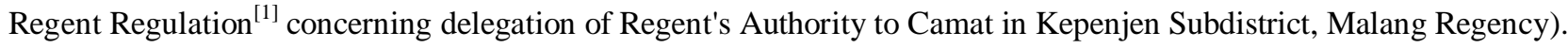

In general, this research aims to seek, find, develop, and test the truth of knowledge. Research is also often carried out to find solutions to developing problems. This study aims to describe and analyze implementation service for building permits based on Malang Regent Regulation ${ }^{[1]}$ concerning delegation of the Regent's Authority to the Camat in Kepenjen District, Malang Regency. To describe and analyze the inhibiting and supporting factory service for building permits based on Malang Regent Regulation.

\section{LITERATURE REVIEW}

The policy is a product resulting from the administration of the government. Policies are in the form of decisions or actions that directly regulate the management and distribution of natural, financial, and human resources for the public interest, namely the people, residents, communities, or citizens. In English, we often hear the policy concept with the term policy. Meanwhile, in the Big Indonesian Dictionary, public policy can be defined as a series of images and principles that become the outline and basis of a plan in the implementation of a job, leadership, and ways of acting (about government, organization, etc.); a statement of ideals, goals, principles, and guidelines for management in achieving goals.

Defines policy as a series of actions/activities proposed by a person, group, or government in a particular environment where there are obstacles (difficulties) and opportunities for the implementation of the proposal. Policy to achieve specific goals. The opinion described shows that policy ideas will involve behavior that has intentions and goals as an essential part of the policy definition because the policies made must show what is done rather than what is proposed in some activities on a problem.

According to the policy exists because of two factors: social problems and the change of power that causes the procedure to change. There are two consequences arising from the determination of the policy. First, policies are oriented towards public services, in the sense that they are by the meaning of democracy. Second, guidelines that poison the public/policies are set only for the benefit of a few groups, and the second impact is very counterproductive to democratic values.

As we have seen, why do we need to know and understand every existing policy? Because policies cannot be understood textually, there are many implied (conceptual) things that are not known by the public in setting policies. Media as a facilitator role for transforming information to the public is essential. Thus, every existing media must be independent or not influenced by certain political powers.

Implementation is an action or implementation of public policy to achieve its goals. There are two choices of steps in implementing public procedures: implementation in the form of programs or through the formulation of derivative policies or derivatives of these general policies.

The meaning of implementation according to that reviewing the problem of policy implementation means trying to understand what happened after the program was declared enacted, namely the events and activities that occurred after the policy ratification 
process, both regarding efforts to administer it and to have a tangible impact on society or specific circumstances. Furthermore, Mazmanian and Sabatier in ${ }^{[7]}$ formulate in more detail the process of implementing state policy as follows:

"Implementation is the implementation of fundamental policy decisions, usually in the form of laws, but can also take the form of critical executive orders or judgments or decisions of the judiciary. Typically, the decision identifies the problem to be addressed explicitly states the goals/targets to be achieved and various ways of structuring/regulating the implementation process. This process takes place after going through a certain number of stages, usually starting with the ratification of laws, then policy outputs in the form of implementing these decisions by the target groups, the actual impacts, whether desired or not, from these outputs."

As explained by ${ }^{[7]}$ in general, it can be demonstrated that the function of policy implementation is to touch a relationship that allows the goals or objectives of state policies to be realized as an outcome (impact) of activities carried out by the government. Therefore, the implementation function also includes creating what in the science of state administration is called a policy delivery system, which usually consists of specific methods or means that are specifically designed and directed towards the achievement of goals and objectives - the desired target.

The complexity in the policy implementation stage is shown by the number of policy actors involved and the variables involved. Mentions ${ }^{[8]}$ several theoretical implementations of policies that say these various variables. Various experts have translated the understanding of policy implementation, including George C. Edwards III, Daniel A. Mazmanian and Paul A. Sebatier, Cheema and Rondinelli, Merilee S. Grindle, Donald Van Meter, Carl Van Horn, and David L. Weimer, and Aidan R. Vining ${ }^{[10]}$.

Without effective implementation, policymakers' decisions will not be successfully implemented. Policy implementation is an activity seen after issuing the right directions from a policy that includes efforts to manage inputs to produce outputs or outcomes for the community. Explains that policy implementation is influenced by four variables: communication, resources, disposition, and Bureaucratic Structure.

The four variables that proposed will be interrelated and interrelated. This interdependence relationship is a goal to achieve the goals of public policy. The illustration of this relationship can be seen in Figure 1 below.

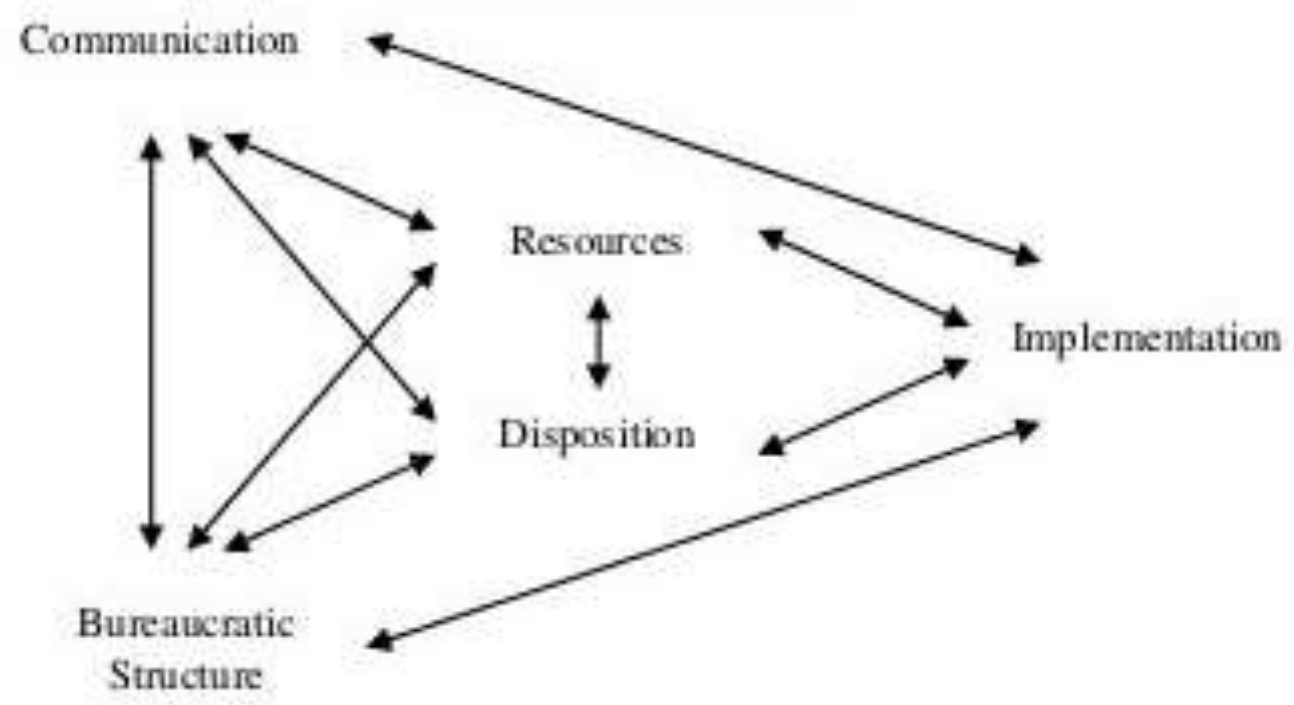

Figure 1 Factors Affecting Policy Implementation

Communication must be transmitted to the right personnel and must be clear, accurate, and consistent states: "Orders to implement policies must be transmitted to the appropriate personnel, and they must be clear, accurate, and consistent." In this case, Edwards explained that if the decisionmaker hopes that the implementation of the policy is as he wants, he must provide the correct information. Proper communication also avoids discretion/discretion on implementers because they will try to explain general guidelines into specific actions. This discretion does not need to be exercised if clear and precise rules about what needs to be done. However, Rules that are too rigid can also hinder implementation because it will make it difficult for implementers to adapt. In this case, a policy that transitions to implementing agents is needed that is appropriate, clear, and consistent but does not hinder the adaptation of these implementing agents.

Regarding resources, explains that the things needed for effective implementation are: 
"Necessary resources include staff of the proper size and with the required expertise; relevant and adequate information on how to implement policies and on the compliance of others involved in implementation; the authority to ensure that procedures are carried out as they are intended; and facilities (including buildings, equipment, land, and supplies) in which or with which to provide services."

Regardless of how clear and consistent the implementation order is and how accurately the command is transmitted, the implementation will not be effective if the implementer who implements the policy lacks resources. The resources referred to by Edwards, as mentioned above, include staff, information, authority, and facilities.

In addition to communication and resources, views the disposition of the implementer as an essential factor states: "If the implementation is well-disposed toward a particular policy, they are more likely to carry it out as the original decisionmakers intended. But when implementors' attitudes or perspectives differ from the decisionmakers, the process of implementing a policy becomes infinitely more complicated." In this case, emphasizes that the attitude of what he calls the disposition is crucial because if the policy implementer has a disposition that is opposite to the direction of the policy, then this perspective can also result in a mismatch between the actual policy objectives and the implementation of the procedure in the field.

The fourth factor that Edward put forward is the bureaucratic structure states that two sub-variables significantly influence the bureaucracies are Standard Operating Procedures (SOP) and fragmentation. Regarding SOPs, explains: "The former develop as internal responses to the limited time and resources of implementors and the desire for uniformity in the operation of the complex and widely dispersed organization; they often remain in force due to bureaucratic inertia." If we rephrase, SOP is a response that arises from the implementor to answer job demands due to lack of time and resources and the provision of uniformity in complex organizational operations. We often encounter this SOP in community service at public service organizations.

\section{RESEARCH METHODOLOGY}

The scope of research, there needs to be a scientific scope as a limitation in conducting scientific research-the explanation obtained about the rules of a subject on the problem that the author describes. With the restriction of the study, the author will focus more on getting problem-solving. The scope of this research is limited to the service of building permits in the Kepanjen District, Malang Regency.

The research location to be carried out by researchers is in Kepanjen District, Malang Regency. As an institution that organizes public services, especially services for building permits. Kepanjen Subdistrict, as a regional work unit in the Malang Regency Government, also has a community service function. Public services carried out in Kepanjen District continue to improve both aspects of the organization, human resources, and processes. The success of bureaucratic reform in the Kepanjen District is part of the needs of the people of Malang Regency.

Informant, as a source of data required by the author, demanded informants who come from internal and external research sites, namely: District Head of Kepanjen Malang Regency; Plt. Head of Public Service in Kepanjen District, Malang Regency; and Kepanjen District public service officer

Data collection technique, according to Robert G. Burgess, a professor from the University of Warwick, the most prominent element of research projects is collecting data using various approaches and in terms of analysis. The data collection methodology will be influenced by the problem being studied. Data collection in research can be done based on experience gained in the field or the laboratory. However, the data obtained must be by the procedure because it will affect the truth of the data.

Data analysis technique in this study, the author uses the theory of analysis, which states that data analysis activities consist of three streams of activities that co-occur, namely data reduction, data presentation, and conclusion drawing/verification ${ }^{\text {[9] }}$. These three activities will be mutually sustainable and influence each other before, during, and after data collection to build general insights known as analysis.

\section{RESEARCH FINDINGS}

The service process for building permits at the sub-district level, the policyholder in granting permits is the sub-district head. This has been stipulated in Malang Regent Regulation ${ }^{[1]}$ concerning Delegation of Regent's Authority to Camats that Camats are given the authority to administer government at the District level. Through interviews with the Kepanjen sub-district head, it is hoped that researchers can obtain information related to various policies in delegating the authority of the Regent to the camat. 
An interview with Mr. Abai Saleh, S.Sos., MM who is the Head of Kepanjen Kaupaten Malang was held on Monday 19 July 2021 at the Kepanjen District Office of Malang Regency. The explanation from the Kepanjen Sub-district of Malang Regency regarding the dynamics of the regulation of building permits and how it is implemented in Kepanjen District, Malang Regency, is explain ed as follows Interview with Mr. Abai Saleh, S.Sos., MM, Monday 19 July 2021:

"This building permit service is one of the essential services at the sub-district level. This has been stipulated in Malang Regent Regulation No. 22 of 2015 concerning the Delegation of Regent's Authority to Camat. So, these duties and authorities can be followed up at the District level. The purpose of this Perbup is to create effective and efficient public services. In its implementation, it is only natural that there are differences in the conditions in the field. The service mechanism itself can be said to be by the procedure. If the permit administrator has met the requirements, we will process it. It is also necessary to emphasize that the IMB described in Perbup 22 of 2015 regarding building permits is only for residential houses. So for business buildings or others, it has become the domain of the Investment Service and One-Stop Integrated Services. The purpose of this regulation is to make it easier for people who have houses to take care of their legality."

The Head of Kepanjen also explained further how important it is for the community to have a building permit, where the benefits will be felt by the owner of the building permit certificate. Interview with Mr. Abai Saleh, S.Sos., MM, Monday 19 July 2021 :

"This IMB is a permit given by the Regional Government to building owners to change, expand, etc., by administrative and technical requirements. So there are two requirements here. Both of these must be met by the conditions. Well, simply put, this IMB is the legality of the building you own. The picture is like this: a building with a value of 100 million was built on a plot of land. Well, if there is no IMB, in the eyes of the bank, it will be of no value. So the benefit of the ownership of this IMB is that the community has legal protection. When there is relocation or development, it cannot be done carelessly. The selling price of a house with an IMB ownership also has a higher value than a house without an IMB. The most crucial thing in this IMB ownership is the community's buying and selling process."

Based on interviews with the Head of Kepanjen Malang Regency, researchers can conclude that the building permit stipulated in Malang Regent Regulation ${ }^{[1]}$ concerning Delegation of Regent's Authority to the Camat is only for residential houses. As for business buildings or the like, it is not the authority of the Head of Kepanjen Malang Regency.

Further interview with Mrs. Widiawati, S.STP., also explained the mechanism for building permits at the Kepanjen District Office, Malang Regency. Interview with Mr. Anggi Dwi Prasetyo, Wednesday 14 July 2021 :

"For procedures, my position as Plt. The Head of the Public Service Section has the task of validating files from incoming applicants. Not infrequently, there is a lack of files, so we have to contact the applicant to complete files that are not appropriate or incomplete. Then for the preparation of the survey schedule with the Environmental Service, I still have to communicate first to avoid miscommunication. I also have to correct it first to minimize errors when the file is already on the leadership desk for drafting."

Researchers also tried to get information from the staff of the public service section who directly provide services to the community. Interview with Mr. Anggi Dwi Prasetyo, Wednesday 14 July 2021:

"For the procedure itself, we are guided by the Perbup that has been stipulated. When I started handling public services at the District Office, I was provided by the leadership to study the Perbup. But yes, when the field is running, it will provide services to the community. There are no significant difficulties. It's just that the name is facing the community; the characters are different. Sometimes it's easy to direct; sometimes, it's difficult to control. It's called the community, right? Moreover, if you have been dealing with older adults, you have to be patient with them."

Furthermore, the researchers also asked about the service process for building permits to the staff of the Public Service Section in Kepanjen District, Malang Regency, namely interview with Mr. Anggi Dwi Prasetyo, as follows at Wednesday 14 July 2021 :

"Our service procedure for building permits in Kepanjen District is guided by the SOPs that have been set. Before applying for a building permit, the applicant must have prepared the required documents. The service process with the community is carried out at the PATEN service counter at the Kepanjen District office. After the officer receives the file, we process whether or not it is eligible to issue a permit certificate. We must also review the site to determine the eligibility of the permit location. After we have approval from the Technical Service, we can only make a draft of a building permit certificate. Only then can a certificate of building construction permit be printed, and only then can it be submitted to the applicant."

A further explanation regarding the service process for building permits was explained again by Mr. Anggi Dwi Prasetyo, namely: "After the applicant has filled out the application form, we will validate and schedule a field survey. The survey process will be carried out by a team from Kepanjen District and the Malang Regency Environmental Service. If the study gets 
inappropriate results, then the application file will be returned to the applicant. Meanwhile, the eligible surveys will then be processed to issue a draft permit. Then the section head will determine the retribution fee and issue a draft permit. Once the draft has been submitted, it will be forwarded to the sub-district head through the secretary. If there is no revision, the District can issue the certificate offered to the applicant through the public service counter in the Kepanjen sub-district."

\section{CONCLUSION}

Based on the results of research in the field and interviews with the implementers of the policy for building permits in Kepanjen District, Malang Regency, the following conclusions were obtained:

Indicators of Implementing Building Permits in Kepanjen District, Malang Regency, Implementation of the service mechanism for building permits in Kepajen District, Malang Regency has been running according to the procedures set out in Malang Regent Regulation No. 22 of 2015 concerning Delegation of Regent's Authority to Camat. The stages carried out by the Kepanjen District, Malang Regency is also by the duties and functions of technical implementers in the Kepanjen District, Malang Regency.

In connection with the Regional Regulation regarding the determination of retribution fees as stated in the Malang Regent Regulation $^{[1]}$ concerning delegation of Regent's Authority to Camat still uses Malang Regent's Regulation ${ }^{[2]}$ concerning Certain Licensing Retribution. Meanwhile, the regulation has been updated with the Malang Regency Regional Regulation Number 1 of 2020 concerning Amendments to Regional Regulation Number 9 of 2010 concerning Certain Licensing Fees. However, there is no change in the discussion on the determination of the building permit levy.

The apparatus resources in Kepanjen District have a pretty good commitment and responsibility. Even though there are multiple positions and limited apparatus resources, the public service process can still run smoothly.

Availability of funds, Kepanjen District, budgets funds to implement public service activity programs. This program must still be implemented even though there is a budget refocusing.Factors Affecting the Implementation of Building Permits in Kepanjen District, Malang Regency. The main internal supporting factor is the commitment and responsibility of implementing policies in the Kepanjen District, Malang Regency, which is very good. They still try to complete the job well even though there are various limitations of apparatus resources. An adequate budget for program implementation also supports this. At the same time, the external supporting factor is establishing good communication between the parties involved in the service process for building permits - the party involved in the Department of Environment of Malang Regency in surveying licensing locations.

The internal inhibiting factor in this research is a vacancy in Kepanjen District. This gives rise to dual positions. In addition, it will also cause a buildup of work which results in a less than optimal service process. In addition, the resources of the apparatus are limited. With such a complex number of services, the number of staff in the public service section is only two people. At the same time, the External Barrier Factor is the difficulty of understanding the public in understanding public service procedures.

\section{REFERENCES}

1. Malang Regent Regulation Number 22 of 2015 concer ning Delegation of Regent's Authority to Camat

2. Malang Regency Regional Regulation Number 9 of 2010 concerning Certain Licensing Retribution

3. Madiasmoro. (2002). Public sector accounting. Yogyakarta: ANdi Yogyakarta.

4. Rosramadhana, BA (2018). Strategy and Socio-Political Problems of Indonesian Regional Autonomous Government. Jakarta: Indonesian Torch Library Foundation.

5. Sinabela, Lijan Poltak. (2016). Human Resource Management. Jakarta: PT Bumi Aksara.

6. Sirajuddin et al. (2011). Public Service Law. Malang: Equivalent to Pres.

7. Abdul Wahab, S. (2008). Policy Analysis from Formulation to Implementation of State Policy. Jakarta: Earth Literacy.

8. Subarsono. (2011). Policy Analysis of Public Policy (Concepts, Theories, and Applications). Yogyakarta: Student Library.

9. Nafi, M., Supriadi, B., \& Roedjinandari, N. (2018). Internal Marketing Impact On External Service Quality In Semeru Pine Forest ( Spf ) Tourist Attraction. IOSR Journal of Business and Management (IOSR-JBM), $20(7), 66-72$. https://doi.org/10.9790/487X-2007016672

10. Intan, D., Sari, P., Widjajani, R., \& Noor, T. (2022). Implementation Of E-Government In Improving Public Service: The Policy of the Directorate General of Taxes at the South Malang, in Indonesia. 8(2), 42-46. https://doi.org/10.31695/IJASRE.2022.8.2.6 